\title{
KEKUATAN HUKUM PEMBUKTIAN REKAM MEDIS KONVENSIONAL DAN ELEKTRONIK BERDASARKAN HUKUM POSITIF INDONESIA
}

\author{
Chris Anggi Natalia Berutu ${ }^{1}$, Yanti Agustina ${ }^{2}$, Sonya Airini Batubara ${ }^{3}$ \\ Dosen Program Studi lmu Hukum, Fakultas Hukum, Universitas Prima Indonesia \\ Jalan Sekip Simpang Sikambing, Medan, Sumatera Utara, 20112 \\ ${ }^{1}$ chrisangginataliaberutu@unprimdn.ac.id ; ${ }^{2}$ yantiagustina@unprimdn.ac.id; \\ ${ }^{3}$ sonyaairinibatubara@unprimdn.ac.id
}

\begin{abstract}
Medical records are files containing patient records, which are made chronological time. There are two types of medical records and in general have been regulated in Permenkes Number 269 / MENKES / PER / III / 2008 concerning Medical Records, namely conventional medical records and electronic medical records. One of the benefits of medical records is as evidence in the law enforcement process. This type of research is normative juridical research and is analytical descriptive in nature. The data source used in this research is secondary data, which is obtained from books, journals, expert opinions and others. The data collection technique used is to collect data in this study through documentation studies in the form of data collection from literature or scientific writing in accordance with the object under study. Data analysis is data obtained and then analyzed qualitatively. From the study it is concluded that the difference in the strength of evidence lies in the non-fulfillment of the requirements of electronic medical records as written / letter evidence, in accordance with the Criminal Code Book 4, Concerning Evidence and Expiration, Second Chapter on Evidence by Writing and KUHAP Article 184 paragraph (1) letter $\mathrm{c}$ and d, as well as Articles 187 and 188 paragraph (2) letter $b$. This means that conventional medical records can be used as original written evidence, whereas electronic medical records cannot. The cause of the difference is because both the Criminal Code and the Criminal Procedure Code, the power of written evidence, is only in writing, in the form of original letters and / or authentic deeds. The data used are (1) primary data in the form of statutory regulations, results of interviews with hospitals and courts, (2) secondary data through literature studies of various laws and regulations and books / journals to obtain expert opinion. The results of this research are expected to be published through (1) scientific articles in Accredited National J ournals and (2) teaching materials in Law courses at the Faculty of Law at Prima Indonesia University.
\end{abstract}

Keywords: Proof; Medical records; Conventional; Electronics, Law Enforcement

Intisari, Rekam medis adalah berkas berisi catatan tentang pasien, yang dibuat berdasarkan kronologis waktu. Terdapat dua jenis rekam medis dan secara umum telah diatur dalam Permenkes Nomor 269/MENKES/PER/III/2008 tentang Rekam Medis yaitu rekam medis konvensional dan rekam medis elektronik. Salah satu manfaat dari rekam medis adalah sebagai alat bukti dalam proses penegakan hukum. Jenis penelitian yang digunakan adalah penelitian yuridis normatif dan sifatnya deksriptif analitis. Sumber data yang digunakan dalam penelitian ini adalah data sekunder, yang diperoleh dari buku, jurnal, pendapat ahli dan lainlain. Analisis Data adalah data yang diperoleh kemudian dianalisis secara kualitatif.Dari penelitian disimpulkan bahwa Perbedaan kekuatan pembuktian terletak pada tidak dipenuhinya syarat rekam medis elektronik sebagai alat bukti tertulis/surat, sesuai dengan KUHPer Buku 4, tentang Pembuktian Dan Daluarsa, Bab Kedua tentang Pembuktian Dengan Tulisan dan KUHAP Pasal 184 ayat (1) huruf $c$ dan d, serta Pasal-Pasal 187 dan 188 ayat (2) huruf b. Artinya rekam medis konvensional dapat digunakan sebagai alat bukti asli tertulis, sedangkan rekam medis elektronik tidak. Penyebab dari perbedaan itu karena baik KUHPer maupun 
KUHAP, kekuatan pembuktian tulisan, hanya dalam bentuk tulisan, berupa surat asli dan/atau akta autentik.

KataKunci: Pembuktian; Rekam Medis; Konvensional; Elektronik,Penegakkan Hukum

\section{Pendahuluan}

Rekam medis diatur dalam beberapa Undang-Undang, yaitu Undang-Undang Nomor 29 tahun 2004 tentang Praktik Kedokteran, Undang-Undang Nomor 44 Tahun 2009 tentang Rumah Sakit serta Permenkes Nomor269/MENKES/PER/III/2008 tentang Rekam Medis, sebagai pelaksanaan Pasal 47 ayat (3) Undang-Undang Nomor 29 tahun 2004 tentang Praktik Kedokteran. Di dalam kedua peraturan yang disebutkan di atas itu, disebutkan mengenai kewajiban seorang dokter dan dokter gigi untuk membuat rekam medis secara lengkap, jelas dan akurat. Bahkan dalam Permenkes tersebut juga disebutkan mengenai pentingnya membubuhkan identitas nama, waktu dan tanda tangan.

Rumah sakit berperan penting mewujudkan kesehatan masyarakat yang optimal, sehingga dituntut mampu mengelola kegiatannya dengan mengutamakan pada tanggung jawab profesionalnya. Rumah sakit dituntut mampu mengelola kegiatannya dengan mengutamakan tanggung jawab secara profesional oleh tenaga medis dan tenaga perawat dalam menjalankan tugas dan kewenangannya. Di dalam Undang-Undang Nomor 44 Tahun 2009 tentang Rumah Sakit juga disebutkan mengenai rekam medis. Di dalam Undang-Undang ini, rumah sakit diwajibkan menyelenggarakan rekam medis, sebagai suatu bentuk pencerminan pelayanan kesehatan yang bertanggung jawab.

Di dalam Permenkes Nomor 269/MENKES/PER/III/2008 tentang Rekam Medis, memang telah disebutkan mengenai terdapatnya dua jenis rekam medis yaitu rekam medis konvensional dan rekam medis elektronik. Namun mengenai rekam medis elektronik ini, tidaklah diatur secara lengkap dan terperinci. Di dalam Pasal 2 ayat (2) Permenkes Nomor 269/MENKES/PER/III/2008 tentang Rekam Medis disebutkan bahwa penyelenggaraan rekam medis dengan menggunakan teknologi informasi elektronik akan diatur lebih lanjut dalam suatu peraturan tersendiri.

Manfaat rekam medis atau rekam medis elektronik yang jelas dan lengkap bagi tenaga medis adalah sebagai dasar atau petunjuk untuk merencanakan dan menganalisis penyakit serta merencanakan pengobatan, perawatan dan tindakan medis yang harus diberikan kepada pasien, serta meningkatkan kualitas pelayanan untuk melindungi tenaga medis dalam pencapaian kesehatan masyarakat yang optimal. Sedangkan kegunaan medis atau rekam medis elektronik bagi pasien antara lain adalah sebagai dasar dalam mengetahui perhitungan biaya pembayaran pelayanan medis yang harus atau telah dikeluarkannya dan perkembangan penyakit, pengobatan, dan tindakan medis. ${ }^{1}$

Berdasarkan latar belakang di atas, maka batasan masalah dalam penelitian ini adalah Bagaimana kekuatan hukum pembuktian rekam medis secara konvensional dan

\footnotetext{
${ }^{1}$ Bandingkan dengan sugeng medica, manfaat-rekam-medis https://sugengmedica. wordpress.com /2012/03/06/ (terakhir diakses 13 Mei, 2020).
} 
elektronik berdasarkan hukum positif Indonesia? dan Bagaimana penerapan rekam medis secara konvensional dan elektronik berdasarkan hukum kesehatan?

\section{Metode Penelitian}

Penelitian ini bersifat yuridis normatif, yaitu pendekatan dengan melihat dari segi yuridis normatif (peraturan-peraturan atau norma-norma yang berlaku). Teknik pengumpulan data dilakukan dengan cara studi pustaka dengan metode sistematis yaitu dengan mengumpulkan data dari berbagai sumber pustaka. Lokasi studi pustaka pada Perpustakaan Universitas Prima Indonesia dan Perpustakaan Daerah Sumatera Utara.

\section{Hasil Penelitian dan Pembahasan}

\section{Kekuatan Hukum Pembuktian Rekam Medis Secara Konvensional Dan Elektronik Berdasarkan Hukum Positif Indonesia}

Pada abad 21 lingkup kesehatan memasuki pembaharuan dalam bidang pelayanan, salah satu dari pembaharuan itu yakni ditandai dengan teknologi informasi yang diberikan kepada masyarakat. Contohnya adalah dalam pencatatan pelayanan yang diberikan kepada pasien sebagai penerima pelayanan medis di rumah sakit, yang pada awal pelaksanaannya dilakukan secara konvensional yakni berupa catatan/surat yang didokumentasikan berisikan tentang pelayanan-pelayanan medis terhadap pasien. Dengan adanya pembaharuan teknologi di bidang kesehatan maka rekam medis saat ini tidak hanya dilakukan secara konvensional melainkan dapat dilakukan secara elektronik. Rekam medis secara elektronik diharapkan akan lebih efektif dan efesien dalam pelayanan kesehatan oleh tim medis.

Sesuai dengan program yang direncanakan oleh pemerintah berlandaskan pada dasar Pembangunan Kesehatan, dan untuk mewujudkan Visi Indonesia Sehat 2025, ditetapkan misi Pembangunan Kesehatan, yaitu meningkatkan dan mendayagunakan sumber daya kesehatan yang meliputi sumber daya manusia kesehatan, pembiayaan kesehatan, serta sediaan farmasi dan alat kesehatan. Sumber daya kesehatan meliputi pula penguasaan ilmu pengetahuan dan teknologi kesehatan/kedokteran, serta data dan informasi yang makin penting peranannya. Salah satu data dan informasi (teknologi informasi) tentang kesehatan yang sesuai dengan arus globalisasi adalah Rekam Medis Elektronik (selanjutnya disebut RME). ${ }^{2}$

\footnotetext{
${ }^{2}$ Penulis menggunakan 2 (dua) istilah (termasuk dalam judul) yaitu Rekam Medis (RM) atau Rekam Medis Elektronik (RME) dengan alasan: (1).Perundang-undangan terkait memberikan alternatif bahwa RM harus dibuat secara tertulis (berarti RM) dan secara elektronik (RME). (2). Beberapa Rumah Sakit atau Tenaga Kesehatan masih banyak menggunakan RM atau mem"back up" dengan RME atau RME saja. Berdasarkan hal itu, apabila digunakan 1 (satu) istilah RM, RME dikhawatirkan makna yang dijelaskan menjadi "bias" karena tidak sesuai dengan "sumber" yang dimaksud. Namun dalam beberapa penjelasan, ada yang secara tegas menggunakan istilah yang "single" yaitu RM, RME.
} 
Pembuatan catatan medis atau rekam medis di rumah sakit atau oleh dokter pada kartu pasien di tempat praktik sebenarnya sudah merupakan kebiasaan sejak jaman dahulu, namun belum menjadi kewajiban, sehingga pelaksanaannya dianggap tidak begitu serius. ${ }^{3}$ Seiring dengan perkembangan masyarakat yang sangat dinamis, maka rekam medis menjadi penting. Oleh karena itu, pemerintah Indonesia melalui Departemen Kesehatan telah mengeluarkan Peraturan Menteri Kesehatan Nomor 749a/MENKES/Per/XII/1989Tentang RM/ Medical Records. Dengan diterbitkannya PERMENKES ini, pengadaan rekam medis menjadi suatu keharusan atau telah menjadi hukum yang harus ditaati bagi setiap sarana pelayanan kesehatan, ${ }^{4}$ tetapi pengaturannya masih berkisar rekam medis berbasis kertas (konvensional). Selanjutnya diterbitkan PERMENKES No. 269 Tahun 2008 Tentang RM, yang menjelaskan bahwa" rekam medis harus dibuat secara tertulis, lengkap, dan jelas atau secara elektronik. ${ }^{5}$

Rumah sakit merupakan sebuah institusi perawatan kesehatan profesional yang pelayanannya disediakan oleh dokter, perawat, dan tenaga ahli kesehatan lainnya. Perbandingan antara jumlah tempat tidur rumah sakit dengan jumlah penduduk Indonesia masih sangat rendah. Untuk 10 ribu penduduk cuma tersedia 6 ranjang rumah sakit. ${ }^{6}$ Mengenai ketentuan rumah sakit diatur dalam Undang-Undang No.44 Tahun 2009 Tentang Rumah Sakit, dimana dalam undang-undang tersebut mewajibkan rumah sakit untuk menyelenggarakan rekam medis sebagai bentuk pertanggungjawaban pelayanan kesehatan.

Peran rekam medis sebagai suatu berkas alat bukti tertulis yang sah dalam pembuktian masalah-masalah hukum, etik dan disiplin. Peran fungsi ini dengan jelas disebutkan sebagai salah satu manfaat dari rekam medis dalam Permenkes Nomor 269/MENKES/PER/III/2008 tentang Rekam Medis. Maka dari itu, suatu rekam medis baik konvensional maupun elektronik, harus dipastikan dapat digunakan sebagai alat bukti tertulis yang sah.

Aturan mengenai alat bukti diatur dalam Hukum Perdata dan Hukum Pidana. Secara hukum perdata, alat bukti diatur dalam Pasal 1866 Kitab Undang-Undang Hukum Pidana, menyatakan bahwa alat bukti tulisan (berkas/surat) merupakan alat bukti yang utama dalam hal pembuktian. Secara hukum pidana, alat bukti diatur dalam Pasal 183 dan Pasal 184 Kitab Undang-Undang Hukum Acara Pidana, menyatakan surat merupakan salah satu alat bukti yang sah. Perbedaan kedudukan alat bukti surat dilihat dari ketentuan hukum secara perdata dan pidana sangat jelas, yakni secara hukum perdata merupakan alat bukti utama dalam hal pembuktian, sedangkan dalam ketentuan hukum pidana merupakan salah satu alat bukti yang dianggap sah karena dalam hukum pidana terdapat 5 alat bukti yang dianggap sah secara hukum dan dalam hal pembuktian dibutuhkan minimal 2 alat bukti sah ditambah keyakinan hakim. Ketentuan Pasal 1866 KUHPerdata menyebutkan, Alat bukti meliputi: bukti tertulis; bukti saksi; persangkaan; pengakuan; dan sumpah. Sedangkan Pasal 184 Ayat (1) KUHAP, alat bukti yang sah dalam hukum

\footnotetext{
${ }^{3}$ J. Guwandi, Trilogi Rahasi Kedokteran, UI Press, Jakarta, 1992, hlm 73.

${ }^{4}$ Anton Arifin , supra no 2.

${ }^{5}$ Pasal 2 Ayat (1) PERMENKES Nomor 749a/Menkes/Per/XII/1989

${ }^{6} \mathrm{https} / / /$ id.wikipedia.org/wiki/Rumah_sakit
} 
pidana: (1) Keterangan saksi; (2) Keterangan ahli; (3) Surat; (4) Petunjuk; (5) Keterangan terdakwa.

Berdasarkan konsep hukum pembuktian adalah salah satu cara untuk meyakinkan hakim agar ia dapat menemukan dan menetapkan terwujudnya kebenaran yang sesungguhnya dalam putusannya, bila hasil pembuktian dengan menggunakan alat-alat bukti yang ditentukan oleh undang-undang ternyata tidak cukup untuk membuktikan kesalahan yang didakwakan kepada terdakwa, maka terdakwa harus dibebaskan dari dakwaan, sebaliknya kalau kesalahan terdakwa dapat dibuktikan maka harus dinyatakan bersalah dan dihukum. ${ }^{7}$ Dari sudut pembuktian hukum pidana di pengadilan terkait kesalahan di bidang kesehatan: a. Proses pembuktian perkara pidana di pengadilan adalah menemukan kebenaran materiil atau kebenaran sesungguhnya, artinya pembuktian tidak hanya memerlukan bukti-bukti tertulis tetapi harus dikuatkan oleh alat bukti lain, misalnya saksi ahli; b. Dalam pembuktian, maka keseluruhan atau sebagian dari informasinya dapat dijadikan bukti untuk mendukung upaya pembelaan bagi rumah sakit dan tenaga kesehatan khususnya dokter; c. Saksi ahli selain harus memberikan keterangan yang benar karena disumpah, juga dapat membuktikan bahwa kesaksiannya tersebut beralasan secara keilmuan yang dibuktikan dengan adanya keseluruhan atau sebagian dari informasi di dalam rekam medis pasien terkait; $d$. Alat-alat bukti berupa rekam medis dan kesaksian ahli yang sudah disumpah akan menjadi bahan pertimbangan hakim, dalam memutuskan kasus atas gugatan ada tidaknya kesalahan dokter; e. Gugatan atas perbuatan pidana, karena adanya kesalahan yang diperkuat dengan adanya unsur kesengajaan/kelalaian dari dokter karena tidak mempersiapkan segala sesuatu untuk mengantisipasi risiko yang dapat terjadi/timbul, sehingga pasien menderita cedera fatal bahkan sampai cacat atau meninggal.

Syarat dari suatu Rekam Medis diterima dalam persidangan bila memenuhi:

1. Rekam Medis tidak ditulis dengan pensil;

2. Tidak ada penghapusan;

3. Coretan, ralat hanya dapat dilakukan pada saat itu juga dan diberi paraf;

4. Tulisan jelas dan terbaca;

5. Ada tanda tangan dan nama petugas;

6. Ada tanggal dan waktu pemeriksaan maupun tindakan;

7. Ada lembar persetujuan tindakan medis. ${ }^{8}$

Bila dilihat mengenai pemahaman alat bukti secara perdata dan acara pidana maka rekam medis yang sah sebagai alat bukti berdasarkan kekuatan hukumnya adalah rekam medis secara konvensional karena rekam medis ini memenuhi dua kekuatan pembuktian

7 http://www.definisi-pengertian.com/2015/05/definisi-pengertian-pembuktian-hukum.html (terakhir diakses tanggal 05-10-2020)

8 http://medicalrecord.blogspot.co.id/2004/10/1-kasus-collins-vs-westlake-community.html (terakhir diakses 13 Mei 2020). 
secara hukum yaitu formil dan materil sepanjang alat bukti tersebut diakui oleh para pihak. Sedangkan rekam medis secara elektronik bukan merupakan alat bukti yang sah berdasarkan konsep pengertian alat bukti secara perdata dan acara pidana karena rekam medis ini tidak memenuhi syarat ketentuan aturan hukum baik secara formil maupun materil.

Selain Kitab Undang-Undang Hukum Perdata dan Kitab Undang-Undang Hukum Pidana, rekam medis juga diatur dalam Peraturan Menteri Kesehatan Nomor 269/MENKES/PER/III/2008 Tentang Rekam Medis menyatakan: "Pemanfaatan Rekam medis dapat dipakai sebagai alat bukti dalam proses penegakan hukum, disiplin kedokteran dan kedokteran gigi dan penegakan etika kedokteran dan kedokteran gigi (Pasal 13 Ayat (1) huruf c)."

Dengan adanya Peraturan Menteri Kesehatan Nomor 269/MENKES/PER/III/2008 Tentang Rekam Medis, maka kedudukan rekam medis elektronik sebagai alat bukti dalam hal pembuktian semakin memiliki kekuatan hukumnya. Rekam medis elektronik merupakan alat bukti yang bukti yang sah secara hukum diperkuat oleh UU No 19 Tahun 2016 Tentang Perubahan Atas Undang-Undang Nomor 11 Tahun 2008 Tentang Informasi dan Transaksi Elektronik (UU ITE) jo Peraturan Menteri Kesehatan Nomor 269 Tahun 2008. Ketentuan Pasal 13 Ayat (1) huruf b PERMENKES tersebut mengatakan: pemanfaatan rekam medis "sebagai alat bukti hukum dalam proses penegakan hukum, disiplin kedokteran dan kedokteran gigi dan penegakkan etika kedokteran dan etika kedokteran gigi."

Ketentuan Pasal 5 dan 6 UU ITE menjelaskan:

Pasal 5 :

1. Informasi elektronik dan/atau dokumen elektronik dan/atau hasil cetaknya merupakan alat bukti hukum yang sah.

2. Informasi elektronik dan/atau dokumen elektronik dan/atau hasil cetaknya sebagaimana dimaksud pada Ayat (1) merupakan perluasan dari alat bukti yang sah sesuai dengan Hukum Acara yang berlaku di Indonesia.

3. Informasi elektronik dan/atau dokumen elektronik dinyatakan sah apabila menggunakan sistem elektronik yang sesuai dengan ketentuan yang diatur dalan UndangUndang ini.

Pasal 6:

Dalam hal terdapat ketentuan lain selain yang diatur dalam Pasal 5 Ayat (4) yang mensyaratkan bahwa suatu informasi harus berbentuk tertulis atau asli, Informasi elektronik dan/atau dokumen elektronik dianggap sah sepanjang informasi yang tercantum di dalamnya dapat diakses, ditampilkan, dijamin keutuhannya, dan dapat dipertanggungjawabkan sehingga menerangkan suatu keadaan.

Keberadaan Informasi Elektronik dan/atau Dokumen Elektronik mengikat dan diakui sebagai alat bukti yang sah untuk memberikan kepastian hukum terhadap 
Penyelenggaraan Sistem Elektronik dan Transaksi Elektronik, terutama dalam pembuktian dan hal yang berkaitan dengan perbuatan hukum yang dilakukan melalui Sistem Elektronik. Khusus untuk Informasi Elektronik dan/atau Dokumen Elektronik berupa hasil intersepsi atau penyadapan atau perekaman yang merupakan bagian dari penyadapan harus dilakukan dalam rangka penegakan hukum atas permintaan kepolisian, kejaksaan, dan/atau institusi lainnya yang kewenangannya ditetapkan berdasarkan undang-undang.

Kendala yang dihadapi dalam proses pembuktian ialah keterangan ahli yang diatur dalam pasal 186 KUHAP. Keterangan ahli yang dimaksudkan dapat juga sudah diberikan pada waktu pemeriksaan oleh penyidik atau penuntut umum yang dituangkan dalam satu bentuk laporan dan dibuat dengan mengingat sumpah pada waktu menerima jabatan/pekerjaan tersebut. Apabila hal tersebut tidak diberikan pada waktu pemeriksaan oleh penyidik/penuntut umum, maka pada waktu pemeriksaan Penyidik atau Penuntut Umum di sidang diminta untuk memberikan keterangan dan dicatat dalam berita acara pemeriksaan. Keterangan tersebut diberikan setelah mengucapkan sumpah atau janji di hadapan sidang mengenai kebenaran keterangannya sebagai saksi ahli. Sumpah atau janji yang diberikan sebagai saksi ahli harus dibedakan dengan sumpah /janji yang diucapkan pada waktu menerima jabatan/ pekerjaan (sumpah jabatan).

Keterangan ahli yang dimaksudkan oleh Pasal 186 KUHAP tersebut apabila dikaitkan dengan hubungan antara dokter atau dokter gigi dan pasien dapat dituangkan dalam bentuk baik tertulis maupun tidak tertulis. Keterangan ahli yang berwujud tertulis dapat berupa rekam medis atau rekam medis elektronik. Fungsi legal dari rekam medis atau rekam medis elektronik ialah sebagai alat bukti apabila terjadi silih pendapat/ tuntutan dari pasien dan di lain pihak sebagai perlindungan hukum bagi dokter. rekam medis atau rekam medis elektronik yang merupakan catatan mengenai dilakukannya tindakan medis tertentu itu secara implisit juga mengandung persetujuan tindakan medis (informed consent), karena tindakan medis tidak akan dilakukan apabila tidak ada persetujuan dari pasien.

Apabila Rekam Medis atau Rekam Medis Elektronik yang mempunyai multifungsi tersebut dikaitkan dengan Pasal 184 KUHAP, maka Rekam Medis atau Rekam Medis Elektronik selain berfungsi sebagai alat bukti surat juga berfungsi sebagai alat bukti keterangan ahli yang dituangkan sebagai isi Rekam Medis. Isi Rekam Medis atau Rekam Medis Elektronik adalah milik pasien. Dokter wajib menjaga kerahasiaannya, berbentuk ringkasan yang dapat diberikan, dicatat, atau dicopy ${ }^{9}$ oleh pasien atau orang yang diberi kuasa atau atas persetujuan tertulis pasien atau keluarga pasien yang berhak untuk itu. Penjelasan isi Rekam Medis atau Rekam Medis Elektronik dapat dilakukan apabila diperlukan sebagai alat bukti dalam proses penegakan hukum, disiplin kedokteran dan kedokteran gigi dan penegakan etika kedokteran dan etika kedokteran gigi. Informasi

\footnotetext{
${ }^{9}$ Young v. Madison General Hospital, 40 Oll.App.3rd.113, 351 N.E. 2nd 276 (1976). Rumah Sakit tidak wajib membuat fotocopi secara Cuma-Cuma. Rumah Sakit berhak untuk memolak pembuatan fotocopi dari RM pasien yang tebal. Rumah Sakit boleh mengizinkan pemohon untuk melihat RM aslinya dan menunjukan bagiaa-bagian mana yang hendak dibuat fotocopi atas biaya pemohon. Lihat J Guwandi, supra catatan no 14, 235.
} 
tentang identitas, diagnosis, riwayat penyakit, riwayat pemeriksaan dan riwayat pengobatan dapat dibuka dalam hal antara lain untuk memenuhi permintaan aparatur penegak hukum dalam rangka penegakan hukum atas perintah pengadilan.

Penjelasan tentang isi rekam medis atau rekam medis elektronik hanya boleh dilakukan oleh dokter atau dokter gigi yang merawat pasien dengan izin tertulis pasien atau berdasarkan peraturan perundang-undangan. Sedangkan pimpinan sarana pelayanan kesehatan dapat menjelaskan isi rekam medis atau rekam medis elektronik secara tertulis atau langsung kepada pemohon tanpa izin pasien berdasarkan peraturan perundangundangan. Dalam hal demikian, atas perintah pengadilan, dokter, dokter gigi yang bertanggungjawab atas perawatan pasien atau pimpinan rumah sakit dapat memberikan fotokopi rekam medis di samping kesimpulan (yang merupakan pendapatnya). Fotokopi ini memang tidak ditegaskan dalam PERMENKES No 269/2008, tetapi merupakan pendapat pakar hukum karena rekam medis atau rekam medis elektronik berfungsi sebagai alat bukti. Hal ini berarti bahwa hakim dapat menggunakan rekam medis atau rekam medis elektronik tersebut sebagai alat bukti di sidang pengadilan, namun tidak mengikat sifatnya, dan masih tergantung pada penilaian hakim. Dengan demikian, rekam medis atau rekam medis elektronik dapat digunakan sebagai dasar untuk membuktikan ada tidaknya kesalahan/kelalaian dokter/dokter gigi dalam melaksanakan profesi, dan di segi lain rekam medis atau rekam medis elektronik dapat digunakan sebagai dasar pembelaan/perlindungan hukum bagi dokter/dokter gigi terhadap gugatan/tuntutan yang ditujukan kepadanya.

Penggunaan rekam medis atau rekam medis elektronik sebagai alat bukti di pengadilan hanya dimungkinkan apabila para pihak yaitu dokter atau dokter gigi, pasien dan penuntut umum mengajukan rekam medis atau rekam medis elektronik sebagai alat bukti untuk menemukan kebenaran materil, dan memperjelas ada tidaknya kesalahan/kelalaian dokter atau dokter gigi dalam melaksanakan profesinya. Dengan demikian rekam medis atau rekam medis elektronik merupakan alat bukti bahwa dokter atau dokter gigi telah mengupayakan semaksimal mungkin melalui tahapan proses upaya pelayanan kesehatan sampai kepada satu pilihan terapi yang paling tepat yang berupa tindakan medis tertentu. Bagi pasien, rekam medis atau rekam medis elektronik merupakan alat bukti yang dapat digunakan sebagai dasar apakah tindakan medis tertentu yang dilakukan oleh dokter atau dokter gigi terhadapnya itu sudah sesuai dengan standar profesi. Berdasarkan itu, dapat disimpulkan bahwa rekam medis atau rekam medis elektronik mempunyai fungsi ganda sebagai alat bukti, yaitu : (1) Sebagai alat bukti keterangan ahli (Pasal 186 dan 187 KUHAP). (2) Sebagai alat bukti surat (Pasal 187 KUHAP).${ }^{10}$ Keterangan yang diberikan secara langsung di persidangan oleh seorang ahli dikategorikan sebagai alat bukti keterangan ahli, sedangkan keterangan ahli yang diberikan di luar persidangan secara tidak langsung (dalam bentuk tertulis) dikategorikan sebagai alat bukti surat.

10 Ameln 1993, http://khoirulanam31.blogspot.co.id/2009/06/rekam-medis-sebagai-alatbukti.html (terakhir diakses 13 Mei , 2020). 


\section{Penerapan Rekam Medis Secara Konvensional Dan Elektronik Berdasarkan Hukum Kesehatan}

Rekam medis harus dibubuhi identitas nama dari dokter, atau tenaga kesehatan tertentu yang mengisi berkas tersebut, waktu pengisiannya dan kemudian harus ditandatangani. Keaslian suatu alat bukti tulisan dapat menjadi masalah apabila tidak jelas dasar hukumnya. Sehubungan dengan hal ini, untuk rekam medis elektronik, akan memerlukan pedoman peraturan yang jelas mengenai penggunaannya. Tanda tangan elektronik, misalnya, yang meskipun sudah disebutkan definisinya dalam UndangUndang Nomor 11 tahun 2008 tentang Informasi dan Transaksi Elektronik, namun masih menunggu pengaturan lebih lanjut, dalam bentuk Peraturan Pemerintah untuk pelaksanaannya.

Sebagai pelaksanaan Pasal 47 Undang-Undang Nomor 29 Tahun 2004 tentang Praktik Kedokteran, ditetapkanlah Permenkes Nomor 269/MENKES/PER/III/2008 tentang Rekam Medis, sebagai pengganti peraturan sebelumnya, yaitu Peraturan Menteri Kesehatan Nomor 749a/Menkes/Per/XII/1989 tentang Rekam Medis. Dalam Permenkes yang baru ini dengan jelas diatur mengenai kewajiban, jenis dan isi masing-masing rekam medis, tata cara penyelenggaraan rekam medis, kewajiban sarana pelayanan kesehatan, sifat rahasia rekam medis, dan berbagai manfaat dari rekam medis.

Namun untuk rekam medis elektronik, sesuai dengan Pasal 2 ayat (2) Permenkes ini, disebutkan bahwa akan diatur lebih lanjut dalam peraturan tersendiri. Hal ini belumlah ada sampai dengan saat ini. Padahal, rekam medis sebagai salah satu dari tiga Doktrin Hukum Kesehatan ${ }^{11}$, harus dipastikan kekuatan hukumnya yaitu sebagai salah satu unsur alat bukti tertulis yang sah dalam proses pengadilan, baik perdata maupun pidana.

Penggunaan rekam medis elektronik sangat efektif dan efisien dibandingkan dengan penggunaan rekam medis konvensional. Perubahan dari rekam medis konvensional ke rekam medis elektronik karena fungsi utama dari rekam medis adalah untuk menyimpan data dan informasi pelayanan pasien. Sayangnya, fungsi ini terbatas bagi rekam kesehatan format kertas yang memiliki banyak kelemahan. Masalah mutu, standarisasi, batas waktu perolehan ataupun kecepatan penyelesaian pekerjaan. Sebagai bandingan, Selain itu rekam medis konvesional juga rawan sobek, rentan air, minyak dan mudah terbakar serta mudah lusuh akibat seringnya penggunaan di pelayanan kesehatan maupun sering salah meletakkan atau hilang. Selain itu tidak dibenarkan dan bahkan menjadi sangat mahal bila setiap rekaman dengan format kertas dibuatkan copy sebagai cadangan. Berbagai kelemahan-kelemahan rekam medis konvensional tersebut yang membuat pihak rumah sakit mulai beralih menggunakan rekam kesehatan elektronik yang lebih menguntungkan. Hal ini juga didukung oleh kemajuan teknologi.

11 Lihat Bambang Poernomo, Hukum Kesehatan, Penerbit Program Pendidikan Pascasarjana Fakultas Kedokteran Magister Manajemen Rumah Sakit Universitas Gadjah Mada, Yogyakarta, hlm. 111 . 
Rekam medis elektronik adalah kegiatan komputerisasi isi rekam kesehatan dan proses elektronisasi yang berhubungan dengannya. ${ }^{12}$ Elektronisasi ini menghasilkan sistem yang secara khusus dirancang untuk mendukung pengguna dengan berbagai kemudahan fasilitas bagi kelengkapan dan keakuratan data, memberi tanda waspada, sebagai peringatan, tanda sistem pendukung keputusan klinik dan menghubungkan data dengan pengetahuan medis serta alat bantu lainnya. Dasar hukum yang mengatur rekam medis elektronik tercantum dalam Permenkes nomor 269/MENKES/PER/III/2008 pada pasal 2 yang berisi "(1) Rekam medis harus dibuat secara tertulis, lengkap, dan jelas atau secara elektronik (2) Penyelenggaraan rekam medis menggunakan teknologi informasi elektronik diatur lebih lanjut dengan peraturan sendiri.

Rekam medis elektronik merupakan catatan rekam medis pasien seumur hidup pasien dalam format elektronik tentang informasi kesehatan seseorang yang dituliskan oleh satu atau lebih petugas kesehatan secara terpadu dalam tiap kali pertemuan antara petugas kesehatan dengan klien. Rekam medis elektronik bisa diakses dengan komputer dari suatu jaringan dengan tujuan utama menyediakan atau meningkatkan perawatan serta pelayanan kesehatan yang efesien dan terpadu.

Hal- hal yang dapat disimpan dalam rekam medik elektronik:

1. Teks (kode, narasi, report)

2. Gambar (komputer grafik, gambar yang di-scan, hasil foto rontgen digital)

3. Suara (suara jantung, suara paru)

4. Video (proses operasi)

Manfaat Rekam Medis Elektronik (EMR) memudahkan pekerjaan dokter dan kebutuhan pasien dalam mendapatkan layanan medis. Hal ini meliputi kemudahan yang ditawarkan dalam sistem sejarah rekam medis pasien, identifikasi dan penanggulangan penyakit, manajemen jadwal kunjungan pasien, serta observasi indikator kesehatan pasien. Selain itu rekam medis elektronik juga memiliki berbagai karakteristik yang dapat memberikan manfaat, karakteristik tersebut antara lain:

1. Akses dapat di lihat dari berbagai tempat

2. Tampilan data dapat dilihat dari berbagai pendekatan

3. Data entry lebih terstruktur

4. Dilengkapi dengan sistem pendukung keputusan

5. Mempermudah dalam analisis data

6. Mendukung pertukaran data secara elektronik dan pemanfaatan data secara bersama sama ( data sharing )

7. Dapat bersifat multimedia

\footnotetext{
${ }^{12}$ https://imamafifhidayat.wordpress.com/2016/10/27/rekam-medis-elektronik-serta-aspek-hukumyang-terkait (diakses terakhir tanggal 05-10-2020).
} 
Dari karakteristik diatas tersebut dapat memberikan tambahan manfaat laiinya yang menguntungkan bahkan memudahkan petugas dalam memberikan pelayanan rekam medis. Adapun manfaat dari pelaksanaan rekam medis elektronik yang lainnya adalah:

1. Penelusuran dan pengiriman informasi mudah

2. Bisa dikaitkan dengan informasi diluar rumah sakit

3. Penyimpanan lebih ringkas, data dapat ditampilkan dengan epat sesuai kebutuhan

4. Pelaporan lebih mudah dan secara otomatis

5. Kualitas data dan standar dapat dikendalikan

6. Dapat diintegrasikan dengan perangkat lunak pendukung keputusan.

7. Lebih cepat dan efisien dalam memberikan pelayanan kepada pasien

8. Keamanan data pasien yang berada di rumah sakit terjamin

9. Tidak membutuhkan kertas, sehingga dapat menghemat penggunaan kertas

10. Dapat melakukan copy cadangan informasi yang dapat diambil apabila terjadi kehilangan data yang asli.

11.Dapat memproses data yang banyak dalam waktu yang singkat.

12.Dapat mengurangi medical error.

\section{Penutup}

Berdasarkan hasil pembahasan maka oleh peneliti dapat ditarik kesimpulan sebagai berikut:

Rekam medis konvensional dan rekam medis elektronik berdasarkan konsep hukum saat ini memiliki kekuatan hukum sebagai alat bukti yang sah dalam hal pembuktian, dimana hal tersebut diatur dan dikuatkan dalam beberapa aturan hukum di Indonesia, antara lain: Kitab Undang-Undang Hukum Perdata, Kitab Undang-Undang Hukum Acara Pidana, Undang-Undang Nomor 29 Tahun 2004 tentang Praktik Kedokteran, dan Permenkes Nomor 269/MENKES/PER/III/2008 tentang Rekam Medis. Rekam medis konvensional sah sebagai alat bukti perihal pembuktian karena memenuhi kekuatan hukum secara formil dan materil (KUHPerdata dan KUHAPidana), sedangkan rekam medis elektronik sah sebagai alat bukti perihal pembuktian karena pemanfaatan dalam proses penegakan hukum, disiplin kedokteran dan kedokteran gigi dan penegakkan etika kedokteran dan etika kedokteran gigi (Undang-Undang Nomor 29 Tahun 2004 tentang Praktik Kedokteran, dan Permenkes Nomor 269/MENKES/PER/III/2008 tentang Rekam Medis).

Rekam medis harus dibubuhi identitas nama dari dokter, atau tenaga kesehatan tertentu yang mengisi berkas tersebut, waktu pengisiannya dan kemudian harus ditandatangani. Keaslian suatu alat bukti tulisan dapat menjadi masalah apabila tidak jelas dasar hukumnya. Penerapan rekam medik konvensional dan elektronik masih 
berlangsung di rumah sakit, namun seiring perkembangan dan pembaharuan teknologi penerapan rekam medik elektronik lebih digunakan karena lebih efektif dan efesien bila dibandingkan dengan rekam medik konvensional yang memiliki banyak resiko dan kerumitan kerja para dokter/medis.

\section{Daftar Pustaka}

\section{A. Buku}

Ariesto Hadi Sutopo dan Adrianus Arief, Terampil Mengolah Data Kualitatif Dengan NVIVO. Penerbit Prenada Media Group, Jakarta, 2010.

Bahder Johan Nasution, Hukum Kesehatan Pertanggungjawaban Dokter, PT. Rineka Cipta, Jakarta, 2005.

Bambang Poernomo, Hukum Kesehatan, Penerbit Program Pendidikan Pascasarjana Fakultas Kedokteran Magister Manajemen Rumah Sakit Universitas Gadjah Mada, Yogyakarta, 2009.

Hayt, Emanuel and Hayt, Jonathan, Legal Aspect of Medical Record, Physician's Record Company, Illinois, 1964.

H. M. Burhan Bungin, Penelitian Kualitatif, Prenada Media Group, Jakarta, 2011.

J. Guwandi, Trilogi Rahasi Kedokteran, UI Press, Jakarta, 1992.

-----, Pengantar Ilmu Hukum Medik Dan Bio-etika, Balai Penerbit Fakultas Kedokteran Universitas Indonesia, Jakarta, 2009.

-----, Rahasia Medis, Balai Penerbit Fakultas Kedokteran Universitas Indonesia, Jakarta, Cetakan 2, 2010.

Joint Commission International, Joint Commission International Accreditation Standards For Hospitals, Department of Publications Joint Commission Resources, USA, 2010.

Lexy J. Moleong, Metodologi Penelitian Kualitatif,PT. Remaja Rosdakarya, Bandung, 2009.

Marguerite Barbacci, et. al., Medical Errors and Litigation: Investigation and Case Preparation, Lawyers and Judges Publishing Company, Inc., Tucson, 2004.

Ronald Dwokrin, dalam Bismar Nasution, Metode Penelitian Hukum Normatif dan Perbandingan Hukum dan Hasil pada Majalah Akreditasi, Medan: Sekolah Pasca Sarjana Universitas Sumatera Utara, 2003.

Rusli Muhammad, Hukum Acara Pidana Kontemporer, Bandung : Citra Aditya Bakti, 2007.

Soerjono Soekanto, Pengantar Penelitian Hukum, UI Press, Jakarta, 1986. 
Tolib Efendi, Dasar-Dasar Hukum Acara Pidana ; Perkembangan Dan Pembaharuanya di Indonesia, Malang : Setara Press, 2014.

\section{B. Perundang-undangan}

Kitab Undang-Undang Hukum Perdata

Undang- Undang Nomor 18 Tahun 1981 Tentang Kitab Undang-Undang Hukum Acara Pidana

Undang-Undang Nomor 29 Tahun 2004 tentang Praktik Kedokteran

Undang-Undang Nomor 11 Tahun 2008 Tentang Informasi dan Transaksi Elektronik

Undang-Undang Nomor 44 Tahun 2009 Tentang Rumah Sakit

PERMENKES Nomor 269 Tahun 2008 Tentang Rekam Medis

\section{Internet}

Ameln 1993, http://khoirulanam31.blogspot.co.id/2009/06/rekam-medis-sebagaialatbukti.html (terakhir diakses $13 \mathrm{Mei}, 2020)$

http://medicalrecord.blogspot.co.id/2004/10/1-kasus-collins-vs-westlake-community.html (terakhir diakses 13 Mei 2020).

sugeng medica, manfaat-rekam-medis https://sugengmedica. wordpress.com /2012/03/06/ (terakhir diakses 13 Mei, 2020).

https://imamafifhidayat.wordpress.com/2016/10/27/rekam-medis-elektronik-serta-aspekhukum-yang-terkait (diakses terakhir 5 Oktober 2020). 